\title{
Pencemaran Logam Berat Kadmium (Cd) dalam Kerang Darah (Anadara granosa) yang Didaratkan di Tambak Lorok Semarang
}

\author{
Erian Febri Satriawan*, Ita Widowati, Jusup Suprijanto \\ Departemen IImu Kelautan, Fakultas Perikanan dan IImu Kelautan, Universitas Diponegoro \\ JI. Prof.H.Soedarto S.H, Tembalang,Semarang, Jawa Tengah 50275 Indonesia \\ ${ }^{*}$ Corresponding author, e-mail : erianfebri.efs27@gmail.com
}

\begin{abstract}
ABSTRAK: Perairan Tambak Lorok Semarang merupakan daerah yang terdapat banyak aktivitas industri. Banyaknya aktivitas industri di perairan Tambak Lorok Semarang dapat menyebabkan tingginya angka pencemaran lingkungan, terutama logam berat. Penelitian ini bertujuan untuk mengetahui kandungan logam berat $\mathrm{Cd}$ (kadmium) pada kerang darah (Anadara granosa) yang terdapat di perairan Tambak Lorok Semarang dan kemudian dilakukan analisis terhadap penilaian resiko kesehatan manusia. Penelitian ini dilaksanakan pada bulan Maret, Juni, Juli dan Agustus tahun 2020 di perairan Tambak Lorok Semarang. Logam berat dari kerang tersebut berdasarkan pembacaan Inductively Coupled Plasma (ICP) menunjukkan nilai $0,280 \mathrm{mg} / \mathrm{kg} ; 0,514 \mathrm{mg} / \mathrm{kg} ; 0,430 \mathrm{mg} / \mathrm{kg}$; dan $1,649 \mathrm{mg} / \mathrm{kg}$. Berdasarkan konsentrasi ratarata Cd lebih rendah dari BSN (2009) yaitu $1 \mathrm{mg} / \mathrm{kg}$ kecuali pada bulan Agustus 2020. Perkiraan asupan harian (EDI) oleh masyarakat berkisar antara $(0,000168-0,000987) \mathrm{mg} / \mathrm{kg} / \mathrm{hari}$. Lalu, nilai bahaya target (THQ) untuk Cd berkisar $(0,161-0,946)$. Nilai ECR yang didapatkan untuk

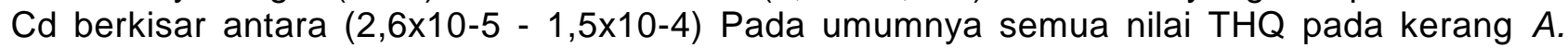
granosa kurang dari 1. Nilai ECR pada kerang $A$. granosa kurang dari 10-4 pada bulan Agustus 2020. Berdasarkan penelitian ini dapat disimpulkan bahwa kerang $A$. granosa yang terdapat di perairan Tambak Lorok Semarang masih bisa untuk dikonsumsi. Dan tidak ada efek buruk kesehatan non-karsinogenik. Namun pada bulan Agustus 2020 memiliki efek karsinogenik. apabila masyarakat mengkonsumsi daging kerang $A$. granosa yang terpapar logam berat kadmium (Cd).
\end{abstract}

Kata kunci : Anadara granosa; ECR; EDI; Logam Berat; THQ

\section{Heavy Metal Cadmium (Cd) Contamination In Blood Shell (Anadara granosa) Landed in Tambak Lorok Semarang}

ABSTRACT: Tambak Lorok Waters in Semarang is an area that has many industrial activities. A large number of industrial activities in Tambak Lorok Semarang waters can cause a high number of environmental pollution, especially heavy metals. This study aims to determine the content of heavy metal Cd (cadmium) in blood clams (Anadara granosa) found in Tambak Lorok waters Semarang. Based on the metal content, an analysis of human health risk assessments was carried out. This research was conducted in March, June, July, and August 2020 in Tambak Lorok waters, Semarang. The heavy metals from these shells based on Inductively Coupled Plasma (ICP) readings showed a value of $0.280 \mathrm{mg} / \mathrm{kg}$ respectively; $0.514 \mathrm{mg} / \mathrm{kg} ; 0.430 \mathrm{mg} / \mathrm{kg}$; and $1.649 \mathrm{mg} / \mathrm{kg}$. Based on the average concentration of Cd is lower than BSN (2009) that is $1 \mathrm{mg} / \mathrm{kg}$ except in August 2020. Estimated daily intake (EDI) by the community ranges from $(0.000168-0.000987) \mathrm{mg} / \mathrm{kg} / \mathrm{day}$. Then, the target hazard value (THQ) for Cd ranges (0.161-0.946). The value of ECR for Cd range between $\left(2,6 \times 10^{-5}-1,5 \times 10^{-4}\right)$. In general, all THQ values in $A$. granosa shells are less than 1 . And then for all $E C R$ value in A. granosa was less than $10^{-4}$. Based on this research, it can be concluded that $A$. granosa shells found in Tambak Lorok Semarang waters are still able for consumption. And there are no adverse non-carcinogenic health effects. But in August 2020 it has a carcinogenic effect. if people consumed $A$. granosa exposed by heavy metal cadmium (Cd).

Keywords: Anadara granosa; ECR; EDI; Heavy metal; THQ 


\section{PENDAHULUAN}

Perkembangan wilayah pesisir utara pulau Jawa khususnya perairan Semarang cukup pesat dengan berbagai macam aktivitas baik berupa jasa kelautan seperti pelabuhan untuk pelayaran dan perikanan maupun kegiatan-kegiatan di sekitar pantai seperti pemukiman, industri, usaha dan pertambakan. Pertumbuhan penduduk dan perkembangan industri sepanjang pantai Semarang sangat mempengaruhi beban pencemaran ke lingkungan pesisir laut (Dewi et al., 2017). Beralih fungsinya lahan terbuka hijau menjadi kawasan industri merupakan sumber utama pencemaran di perairan pesisir Indonesia (Arifin, 2001). Akibat dari berkembangnya industri seperti industri bengkel las, karoseri, percetakan dan pelapisan logam, pestisida, plastik, cat, tekstil, minyak pelumas, bengkel kendaraan bermotor di Kota Semarang, diduga dapat menimbulkan dampak yang positif maupun negatif. Dampak positif bagi kesejahteraan masyarakat diantaranya adalah terciptanya lapangan pekerjaan baru, sementara itu dampak negatifnya adalah dapat meningkatkan jumlah limbah dalam bentuk gas, padat dan cair yang mengandung logam berat. Limbah aktifitas industri terkadang dibuang langsung ke sungai atau ke perairan.

Kontaminan logam di ekosistem pesisir bisa berasal dari tiga kompartemen yaitu air laut, sedimen dan biota. Pengembangan penelitian tentang subjek ini mengikuti ide yang dikembangkan selama tiga dekade terakhir seperti yang disebutkan oleh Arifin (2001). Sumber kontaminan logam berat sudah ada dari zaman dahulu hingga sekarang, yaitu dari tahun 1980 an dan terakumulasi hingga sekarang. Logam berat dalam air laut dapat dibedakan menjadi dua besar komponen, yaitu logam dalam bentuk zat terlarut dan logam yang mengikat untuk partikel tersuspensi atau sedimen. Konsentrasi logam dalam bentuk zat terlarut sebagian besar lebih rendah dari standar kualitas air nasional. Logam berat dapat terakumulasi ke dalam tubuh ikan, udang, kerang dan hasil laut lainnya. Menurut Tielman et al., (2018), kerang darah ( $A$. granosa) memiliki kemampuan sebagai bioakumulator berbagai jenis logam berat yaitu $\mathrm{Hg}, \mathrm{Cd}, \mathrm{Cr}, \mathrm{Cu}, \mathrm{Zn}$, dan $\mathrm{Pb}$. Keadaan tersebut tentunya dapat berakibat fatal bagi organisme maupun bagi masyarakat yang terus mengkonsumsinya sehingga dampak negatif dari logam berat dapat terakumulasi terus menerus pada tubuh manusia. Selain itu kerang $A$. granosa merupakan salah satu komoditas hasil perikanan yang dikonsumsi oleh masyarakat dikarenakan rasanya yang lezat (Yulianto, 2006).

Dengan demikian, penilaian resiko kesehatan dengan pendekatan ARKL akibat mengkonsumsi kerang $A$. granosa harus dilakukan sebagai tindakan pencegahan untuk menjaga kesehatan masyarakat khususnya di pesisir perairan Semarang. Karenanya, penelitian ini bertujuan untuk menyelidiki potensi penilaian. resiko kesehatan pencemaran logam berat dari konsumsi daging kerang darah yang diperoleh dari pesisir perairan Semarang Jawa Tengah dengan menggunakan analisis Tolerable Hazard Quotiens untuk mengetahui adanya efek penyakit nonkarsinogenik dan analisis Excess Cancer Risk untuk resiko karsinogenik yang ada di dalam Analisis Resiko Kesehatan Lingkungan.

\section{MATERI DAN METODE}

Sampel yang diuji adalah sampel kerang darah ( $A$. granosa). Lokasi pengambilan sampel di Perairan Tambak Lorok Semarang. Pengambilan sampel dilakukan pada bulan Maret, Juni, Juli dan Agustus 2020; dimana karena sampling pada masa pandemic COVID19 maka dilakukan dengan memperhatikan protokol kesehatan yaitu membatasi segala interaksi antar manusia. Untuk itu maka sampel diambil dengan cara membeli hasil tangkapan kerang $A$. granosa dari nelayan secara langsung. Pengambilan sampel yang pertama kali dilakukan adalah sebagai uji pendahuluan, yaitu dengan kerang dibeli dari salah satu nelayan di Tambak Lorok untuk memastikan pada lokasi tersebut terdapat kerang yang diduga telah tercemar logam berat $(\mathrm{Cd})$, dan dilakukan pengamatan apakah kerang kemudian dibeli oleh warga sekitar atau tidak. Jika ya, maka dilakukan pengambilan sampel kerang secara langsung dari nelayan di tempat yang merupakan sumber habitat kerang dan merupakan jalur nelayan mengambil kerang. Pengambilan data di lapangan dilakukan tiga (3) kali ulangan untuk mengetahui dinamika kandungan logam berat $\mathrm{Cd}$ pada kerang $A$. granosa dari perairan Semarang. Penelitian ini menggunakan metode deskriptif yang bertujuan untuk membuat gambaran sesuai dengan fakta-fakta yang terjadi di lapangan, karakteristik serta hubungan antar fenomena yang akan diteliti secara akurat dan sistematis (Nazir, 2005). 
Analisa yang kandungan logam berat $\mathrm{Cd}$ pada sampel kerang dilakukkan di Laboratorium Balai Besar Teknologi Pencegahan Pencemaran Industri (BBTPPI) kota Semarang dengan menggunakan metode Inductively Coupled Plasma (ICP) berdasarkan SNI 01-2896-1992. Jaringan lunak kerang darah diambil sebanyak $\pm 5 \mathrm{~g}$ ke dalam cawan porselen dan catat beratnya, kemudan buat control positif $\mathrm{Cd}$ contohnya pembuatan spiked $0,05 \mathrm{mg} / \mathrm{kg} \mathrm{Cd}$ dengan cara menambahkan sebanyak 0,25 ml larutan standar $\mathrm{Cd} 1 \mathrm{mg} / \mathrm{l}$ ke dalam contoh sebelum dimasukan ke tungku pengabuan. Lalu uapkan contoh dan spiked di atas hot plate pada suhu $100^{\circ} \mathrm{C}$ setiap 30 menit hingga mencapai $450^{\circ} \mathrm{C}$ lalu ditunggu hingga 18 jam. Setelah itu spiked dikeluarkan dari tungku pengabuan dan didinginkan pada suhu kamar. Setelah dingin tambahkan $1 \mathrm{ml} \mathrm{HNO}_{3} 65 \%$ goyangkan dengan hati-hati hingga semua abu larut dalam asam dan selanjutnya uapkan diatas hot plate pada suhu $100^{\circ} \mathrm{C}$ hingga kering. Setelah kering masukan kembali contoh dan spiked ke dalam tungku pengabuan dan naikkan suhu secara bertahap $100^{\circ} \mathrm{C}$ setiap 30 menit hingga mencapai $450^{\circ} \mathrm{C}$ lalu ditunggu hingga 3 jam. Setelah abu terbentuk sempurna dan berwarna putih kemudian didinginkan contoh dan spiked pada suhu ruang. Tambahkan $5 \mathrm{ml} \mathrm{HCl} 6 \mathrm{M}$ kedalam masing-masing contoh dan spiked goyangkan secara hati-hati hingga semua abu larut ke dalam asam. Kemudian uapkan diatas hot plate pada suhu $100^{\circ} \mathrm{C}$ hingga kering. Tambahkan $10 \mathrm{ml} \mathrm{HNO}_{3} \quad 0,1 \mathrm{M}$ dan dinginkan pada suhu ruangan selama 1 jam, kemudian pindahkan larutan ke dalam labu takar polypropylene $50 \mathrm{ml}$ dan ditambahkan larutan matrik modifier, tepatkan sampai tanda batas dengan menggunakan $\mathrm{HNO}_{3} 0,1 \mathrm{M}$.

Data pengukuran logam berat $\mathrm{Cd}$ pada kerang $A$. granosa kemudian dibandingkan dengan baku mutu batas cemaran logam berat $\mathrm{Cd}$ yang dapat di toleransi boleh berada pada tubuh kerang yang telah dikeluarkan oleh Badan Standarisasi Nasional (SNI No 7387 tahun 2009).

\section{Efek Non Karsinogenik}

Pada kerang $A$. granosa yang telah diketahui kandungan logam berat nya, kemudian dapat dihitung nilai batas konsentrasi maksimum sebagai bahan makanan. Berdasarkan Irwan et al (2018) nilai akumulasi logam berat pada jaringan lunak kerang $A$. granosa digunakan untuk menghitung perkiraan asupan harian (EDI), nilai bahaya target (THQ) secara terpisah untuk individu. Nilai EDI akan dihitung dengan persamaan menurut USEPA (2011).

$$
\mathrm{EDI}=\frac{\mu \mathrm{g}}{\mathrm{kg}}=\frac{\mathrm{C}(\mu \mathrm{g} / \mathrm{g}) \times \mathrm{FIRg}}{\mathrm{WAB}(\mathrm{kg})}
$$

Keterangan : $\mathrm{C}=$ konsentrasi logam berat; FIR = angka konsumsi kerang dengan asumsi konsumsi ikan (34,7 g/org/hari (BPS 2018); Wab= berat badan rata-rata orang dewasa Indonesia $58 \mathrm{~kg}$ (permenkes 2019)

Dimana $C$ adalah konsentrasi logam pada kerang $A$. granosa $(\mu \mathrm{g} / \mathrm{g})$; FIR adalah tingkat konsumsi kerang di Indonesia. Jika diasumsikan dengan angka konsumsi ikan di Indonesia pada tahun 2018 yaitu sebesar 50,69 /kg/kap/tahun, maka rata-rata konsumsi kerang masyarakat Indonesia per hari adalah (34,7 g/org/hari) berdasarkan BPS (2018); WAB adalah berat badan ratarata untuk pria dan wanita $(58 \mathrm{~kg}$ ) berat badan untuk wanita adalah $56 \mathrm{~kg}$ dan untuk pria $60 \mathrm{~kg}$ berdasarkan angka kecukupan gizi yang dianjurkan untuk masyarakat Indonesia (Permenkes, 2019).

\section{Nilai bahaya target (THQ)}

Nilai bahaya target (THQ) adalah rasio paparan potensial terhadap suatu zat dan tingkat, dimana tidak ada efek buruk yang diharapkan. Nilai THQ lebih dikenal sebagai parameter yang bermanfaat untuk penilaian resiko kesehatan manusia terhadap logam berat yang terkandung dalam kerang (Rayyan et al., 2019). Jika nilai THQ yang dihitung hasilnya kurang dari 1.0, maka tidak ada efek kesehatan yang merugikan sebagai akibat dari terpapar logam berat. Sebaliknya, apabila nilai THQ angkanya lebih dari 1.0, maka efek kesehatan yang buruk kemungkinan dapat terjadi. Berdasarkan Irwan et al (2018) Nilai THQ dapat dihitung menggunakan persamaan menurut (USEPA, 2011). 


$$
\mathrm{THQ}=\frac{\mathrm{EF} \times \mathrm{Ed} \times \mathrm{C} \times \mathrm{FIR}}{\mathrm{RfD} \times \mathrm{WAB} \times \mathrm{ATn}} \times 10^{-3}
$$

Keterangan : EF = paparan frekuensi paparan logam berat (350 hari/tahun) berdasarkan pajanan pada pemukiman (Depkes 2012); Ed = durasi pemaparan logam berat di Indonesia non karsinogenik (30 tahun) (Depkes 2012); RfD= merupakan referensi dosis konsumsi dari logam berat per individu $(0,001 \mathrm{mg} / \mathrm{kg} / \mathrm{hari})$ untuk logam berat $\mathrm{Cd}$ (usepa 2011); $\mathrm{ATn}=$ rata-rata waktu paparan untuk nonkarsinogenik (365 hari/ tahun x 30 tahun) (depkes, 2012)

Dimana EF merupakan frekuensi paparan logam berat (350 hari/tahun) berdasarkan pajanan pada pemukiman (Depkes 2012). ED merupakan durasi pemaparan logam berat di Indonesia non karsinogenik (30 tahun) berdasarkan asumsi bahwa mengkonsumsi daging kerang berturut-turut selama 30 tahun (Depkes 2012). RfD merupakan referensi dosis konsumsi dari logam berat per individu (1 $\mathrm{\mu g} / \mathrm{kg} / \mathrm{hari}$ ) untuk logam berat Cd berdasarkan USEPA (2011). WAB merupakan Weight Body yaitu berat badan orang dewasa $(58 \mathrm{~kg}$ ) rata-rata baik pria $(60 \mathrm{~kg})$ maupun wanita $(56 \mathrm{~kg})$ menurut Peraturan Menteri Kesehatan (2019). ATn merupakan rata-rata waktu paparan untuk nonkarsinogenik (365 hari/tahun x 30 tahun) berdasarkan (USEPA, 2011)

\section{Efek Karsinogenik}

Langkah yang dilakukan untuk menghitung efek karsinogenik pada dasarnya hampir sama namun jika pada penilaian non-karsinogenik nilai Intake atau THQ dibagi dengan Reference dose (RFD). Pada penilaian karsinogenik nilai intake dikalikan dengan Slope Factor (SF) untuk logam berat Cd yaitu 0,38 berdasarkan USEPA (2011), serta rata-rata waktu paparan ATn untuk penilaian karsinogenik menjadi (365 hari/tahun $\times 70$ tahun) atau sesuai dengan angka harapan hidup menurut (Depkes, 2012).

$$
\mathrm{ECR}=\frac{\mathrm{EF} \times \mathrm{Ed} \times \mathrm{C} \times \mathrm{FIR}}{\mathrm{WAB} \times \mathrm{ATn}} \times \mathrm{SF}
$$

Keterangan : ATn= rata-rata waktu paparan untuk karsinogenik ( 365 hari/tahun $\times 70$ tahun) (depkes, 2012); SF = slope factor untuk logam berat Cd yaitu $(0,38)$ (USEPA, 2011)

\section{HASIL DAN PEMBAHASAN}

\section{Kandungan Logam Berat Cd Pada Kerang Darah}

Konsentrasi logam berat kadmium (Cd) pada jaringan lunak kerang darah ( $A$. granosa) adalah sebesar 0,280 mg/kg pada uji bulan Maret 2020, pada pengambilan sampel bulan Juni 2020 konsentrasi logam berat kadmium (Cd) sebesar $0,514 \mathrm{mg} / \mathrm{kg}$, serta pada pengambilan sampel pada bulan Juli dan Agustus 2020 berturut-turut konsentrasi logam berat Cd adalah 0,430 mg/kg dan $1,649 \mathrm{mg} / \mathrm{kg}$. Kandungan logam berat pada bulan Agustus telah melewati angka baku mutu maksimal yang dapat diterima oleh kekerangan, yaitu $1 \mathrm{mg} / \mathrm{kg}$. Baku mutu yang digunakan adalah berdasarkan Badan Standarisasi Nasional (SNI No 7387 tahun 2009).

Berdasarkan hasil analisis logam berat kadmium $(\mathrm{Cd})$ dalam jaringan lunak kerang darah $(A$. granosa), maka perlu diketahui nilai perkiraan asupan harian suatu cemaran logam berat dalam tubuh manusia. Serta nilai bahaya target yang bertujuan untuk mengevaluasi kemungkinan dampak buruk yang dapat ditimbulkan dari suatu jenis logam berat yang dihasilkan dari konsumsi jaringan lunak kerang darah ( $A$. granosa) yang tercemar. Nilai EDI dan THQ dengan asumsi berat badan rata-rata orang dewasa yaitu $58 \mathrm{~kg}$. Nilai EDI pada bulan Maret adalah sebesar $0,000168 \mathrm{mg} / \mathrm{kg} / \mathrm{hari}$, pada bulan Juni perkiraan nilai asupan harian sebesar $0,000308 \mathrm{mg} / \mathrm{kg} / \mathrm{hari}$, pada bulan Juli sebesar $0,000257 \mathrm{mg} / \mathrm{kg} / \mathrm{hari}$, serta pada bulan Juli sebesar $0,000987 \mathrm{mg} / \mathrm{kg} / \mathrm{hari}$. Nilai EDI tersebut kemudian dibandingkan dengan nilai Provisional Maximum Tolerable Daily Intake (PMTDI) yang telah ditetapkan oleh JECFA atau nilai Reference Dose (RfD) yang telah ditetapkan oleh USEPA. Nilai PMTDI atau RfD yang telah dikeluarkan untuk logam berat kadmium (Cd) adalah $0,001 \mathrm{mg} / \mathrm{kg}$. Adapun untuk nilai THQ adalah rasio antara EDI dan RfD. Nilai THQ yang telah dihitung pada 
bulan Maret 2020 adalah 0,161; lalu pada bulan Juni 2020 nilai THQ sebesar 0,295, pada bulan Juli 2020 sebesar 0,247; adapun pada bulan Agustus 2020 sebesar 0,946. Nilai ECR logam berat kadmium Cd pada kerang A. granosa pada bulan Maret 2020, Juni 2020, Juli 2020 dan Agustus

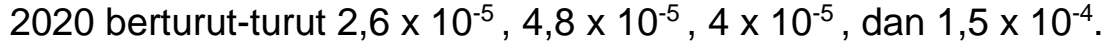

Kerang $A$. granosa merupakan kerang yang paling banyak terkontaminasi logam berat $\mathrm{Cd}$ karena ketersediaan kerang $A$. granosa di perairan selalu ada. Selengkapnya data mengenai kandungan logam berat $\mathrm{Cd}$ pada seluruh kerang dan seluruh logam berat yang terkonsentrasi pada kerang $A$. granosa terdapat pada lampiran. Berdasarkan ukurannya, sampel yang didapat didominasi oleh populasi kerang ukuran besar $(>3 \mathrm{~cm})$ kecuali pada bulan Maret 2020 yang didominasi oleh kerang ukuran sedang $(2,5-3 \mathrm{~cm})$.

Dari hasil yang didapat pada uji pendahuluan bulan Maret 2020 terdapat logam berat $\mathrm{Cd}$ sebesar $0,280 \mathrm{mg} / \mathrm{kg}$, lalu pada sampling ke-1 bulan Juni 2020 ditemukan logam berat Cd sebesar $0,514 \mathrm{mg} / \mathrm{kg}$, pada sampling ke-2 bulan Juli 2020 terdapat logam berat Cd sebesar 0,430 mg/kg sedangkan pada sampling ke-3 yaitu bulan Agustus 2020, logam berat Cd sebesar 1,649 mg/kg. nilai logam berat $\mathrm{Cd}$ sangat bervariatif pada setiap bulannya. Nilai tertinggi terdapat pada bulan Agustus 2020 yaitu sebesar 1,649 mg/kg sedangkan angka terendah didapat pada bulan Maret 2020 yaitu sebesar $0,280 \mathrm{mg} / \mathrm{kg}$. Hasil logam berat Cd yang didapat pada bulan Maret 2020 cenderung lebih kecil daripada bulan Juni, Juli dan Agustus 2020. Hal ini diduga karena perbedaan ukuran mayoritas kerang yang didapatkan. Kerang pada bulan Maret 2020 didominasi oleh kelas ukuran sedang, sementara pada bulan Juni, Juli dan Agustus 2020 didominasi oleh kerang ukuran besar hal ini sesuai dengan pernyataan Ahyar et al. (2017) yang menyatakan cangkang yang berukuran besar akan berkolerasi positif dengan umur yang meningkat, dan umur yang meningkat akan berkoleratif positif juga dengan meningkatnya konsentrasi logam berat pada tubuh $A$. granosa.

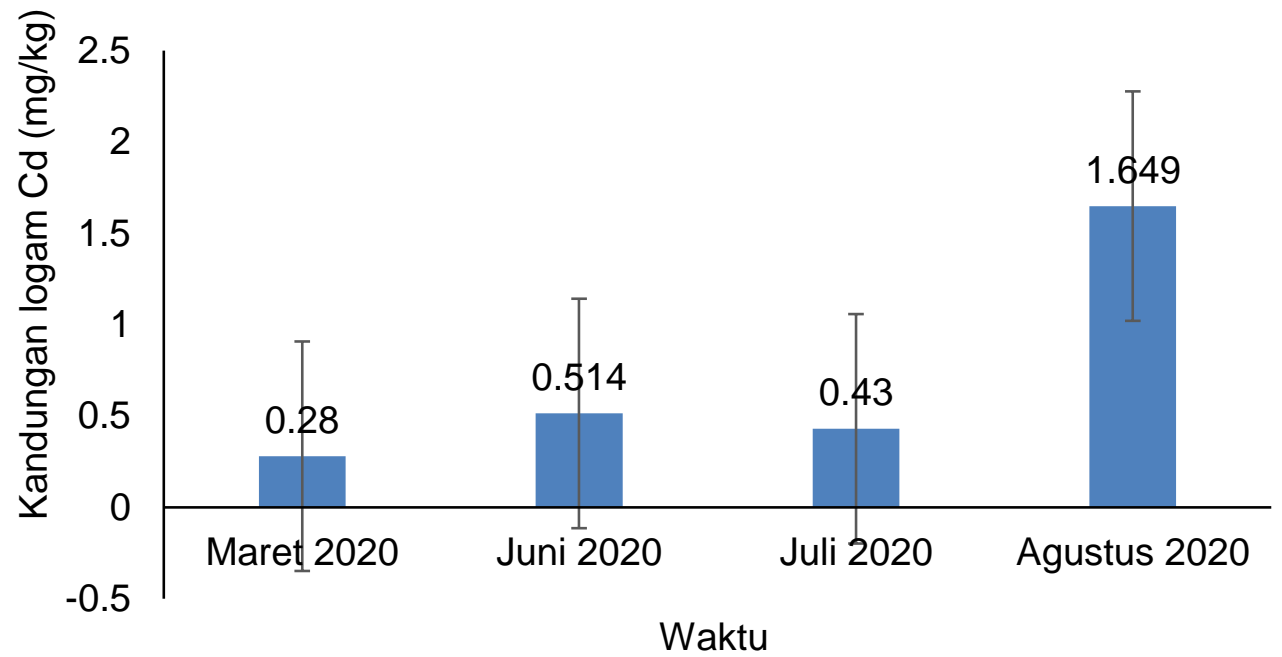

Gambar 1. Grafik Konsentrasi Logam Berat Cd pada Kerang Darah Bulan Maret 2020, Juni 2020, Juli 2020, dan Agustus 2020

Tabel 2. Nilai Perkiraan Asupan Harian (EDI) dan Total Hazard Quotient (THQ), dan nilai Excess Cancer Risk (ECR) pada kerang A. granosa.

\begin{tabular}{cccc}
\hline Bulan & Nilai EDI $(\mathrm{mg} / \mathrm{kg} / \mathrm{hari})$ & Nilai THQ & Nilai ECR \\
\hline Maret 2020 & 0,000168 & 0,161 & $2,6 \times 10^{-5}$ \\
Juni 2020 & 0,000308 & 0,295 & $4,8 \times 10^{-5}$ \\
Juli 2020 & 0,000257 & 0,247 & $4 \times 10^{-5}$ \\
Agustus 2020 & 0,000987 & 0,946 & $1,5 \times 10^{-4}$
\end{tabular}

RfD untuk logam berat $\mathrm{Cd}=0,001 \mathrm{mg} / \mathrm{kg}$ (USEPA, 2011) Batas aman THQ $=1$ (Depkes, 2012) Batas aman ECR $=$ E-4 (Depkes 2012) 
Penelitian mengenai logam berat kadmium (Cd) pada kerang $A$. granosa di Perairan Pantai Bancaran Kabupaten Bangkalan, Madura yang dilakukan oleh Ulfah et al., (2019) menunjukan kandungan logam berat kadmium (Cd) lebih tinggi ditemukan pada kerang dengan kelas ukuran besar. Perbedaan konsentrasi logam berat juga diduga akibat dari kebijakan Pembatasan Sosial Berskala Besar (PSBB) yang pertama kali di keluarkan oleh pemerintah pada saat awal pandemi COVID-19 sehingga segala sektor produksi yang dilakukan oleh pabrik industri maupun yang lainnya cenderung menurun. Hal ini akan mengurangi buangan limbah hasil produksi ke perairan. Sedangkan pada bulan Agustus 2020 hasil logam berat Cd cenderung paling tinggi dari bulan yang lainnya, hal ini diduga karena kebijakan PSBB yang telah di longgarkan sejak bulan Juni 2020 oleh pemerintah dan memasuki masa New Normal yang membuat segala macam aktivitas industri kembali dijalankan sehingga dapat menyebabkan banyaknya hasil buangan limbah ke perairan dan puncaknya pada bulan Agustus 2020 ketika sudah mulai banyak manusia beraktivitas diluar rumah daripada bulan sebelumnya. Hal ini sesuai dengan pernyataan Eldrin et al., (2019) dan Tielman et al., (2018), yaitu penyebab utama pencemaran logam berat di perairan berasal dari zat yang terkontaminasi oleh limbah buangan industri. Distribusi logam berat di lingkungan perairan biasanya berkorelasi dengan kepadatan populasi dan urbanisasi melalui input besar yang tidak terkendali dari industri aktif. Adanya peningkatan serta kontinuitas buangan air limbah industri yang mengandung senyawa logam berat beracun, cepat atau lambat akan merusak ekosistem perairan.

Perbedaan konsentrasi logam berat pada setiap bulannya diduga juga dengan perbedaan curah hujan. Berdasarkan data curah hujan dari Stasiun Meteorologi Maritim Tanjung Mas Semarang, pada bulan Maret 2020 curah hujan cenderung lebih tinggi dan lebih sering terjadi hujan pada setiap harinya daripada bulan Juni 2020, Juli 2020, dan Agustus 2020. Hal ini karena pada bulan Maret 2020 dan kota Semarang masih berada pada musim penghujan. Sedangkan pada bulan Juni 2020, Juli 2020, dan Agustus 2020 curah hujan cenderung lebih rendah dan jarang terjadi hujan pada setiap harinya. hal ini karena pada bulan Juni 2020, Juli 2020, dan Agustus 2020 kota Semarang sudah berada pada musim kemarau. Nilai logam berat pada bulan Juli 2020 lebih rendah daripada bulan Juni 2020 dan Agustus 2020 diduga karena curah hujan pada bulan Juli 2020 lebih tinggi daripada bulan Juni 2020 dan Agustus 2020 berdasarkan data BMKG Tanjung Mas. Menurut Darmono (1995), kandungan logam berat dipengaruhi oleh lingkungan dan musim, pada musim penghujan logam berat akan mengalami pelarutan sedangkan pada musim kemarau logam berat akan terkonsentrasi.

Hasil analisa logam berat pada bulan Maret, Juni, dan Juli tahun 2020 belum melewati ambang batas kontaminasi logam berat kadmium (Cd) yang telah dikeluarkan oleh Badan Standarisasi Nasional (SNI No 7387 tahun 2009) yaitu sebesar $1 \mathrm{mg} / \mathrm{kg}$ untuk logam berat Cd. Tentunya kerang darah pada bulan Maret 2020, Juni 2020, dan Juli 2020 belum menjadi masalah apabila ada yang mengambil komoditas kerang $A$. granosa ini untuk diperjual belikan sebagai bahan konsumsi. Namun kerang darah pada bulan Agustus 2020 perlu diperhatikan lebih khusus karena telah melewati batas aman kontaminasi logam berat $\mathrm{Cd}$.

Perkiraan asupan harian adalah perkiraan dari asupan logam berat yang masuk ke tubuh manusia melalui konsumsi makanan pada setiap harinya. Penilaian EDI berdasarkan pada tingkat konsumsi ( $g /$ hari) kerang dan konsentrasi logam berat dalam kerang tersebut. Nilai tersebut bervariatif tergantung dengan berat badan manusia (Purbonegoro, 2020). Nilai EDI kemudian dibandingkan dengan PMTDI (Provisional Maximum Tolerable Daily Intake) atau RfD (Reference Dose). Nilai RfD merupakan perkiraan maksimum bahan kimia tertentu yang tidak menimbulkan resiko kesehatan bagi manusia yang mengkonsumsi.

Berdasarkan hasil perhitungan nilai EDI, diketahui bahwa nilai EDI pada 4 kali dilakukan pengujian masih dibawah nilai RfD atau referensi dosis harian untuk logam berat Cd yaitu 0,001 $\mathrm{mg} / \mathrm{kg}$. Menurut Departemen Kesehatan Negara Bagian New York (2007), apabila rasio EDI logam berat terhadap reference dose RfD kurang dari atau sama dengan $\mathrm{RfD}$, maka resiko kesehatan akan minimum, jika rasio > 1-5 RfD maka resiko kesehatan rendah, apabila rasio > 5-10 RfD, maka resiko kesehatan akan moderat, tetapi jika rasio > $10 \mathrm{RfD}$, maka resiko kesehatannya akan tinggi. Hal tersebut dapat diindikasikan masyarakat yang mengkonsumsi daging kerang $A$. granosa yang tercemar logam berat $\mathrm{Cd}$ di perairan Tambak Lorok Semarang berdasarkan rata-rata jumlah konsumsi kerang di Indonesia dengan berat badan rata-rata orang dewasa tidak berpotensi mengalami resiko kesehatan yang buruk. Namun apabila dikonsumsi dalam jumlah berlebih, maka 
akan berdampak buruk bagi kesehatan.

Menurut Istarani dan Pandabesie (2014), logam berat kadmium bagi anak-anak dapat membantu perkembangan otak pada anak, namun apabila dikonsumsi dalam jumlah berlebih, logam berat $\mathrm{Cd}$ memiliki efek yang buruk bagi orang dewasa, diantaranya adalah menaikkan resiko penyakit karsinogenik dan non-karsinogenik. Efek karsinogenik seperti kanker payudara, kanker paru-paru atau kardiovaskuler, dan lain sebagainya. Efek non-karsinogenik yang ditimbulkan akibat keracunan logam $\mathrm{Cd}$ adalah kegagalan fungsi ginjal, penyakit jantung, mengalami encok, radang artitis, hingga dapat menimbulkan kerusakan tulang Chen, (2009) dalam Istarani dan Pandabesie (2014) logam berat Cd dapat terakumulasi, dan pada rantai makanan biota tertinggi seperti manusia logam berat $\mathrm{Cd}$ akan terakumulasi lebih banyak. Logam berat $\mathrm{Cd}$ dapat terakumulasi pada manusia dan baru dapat diekskresi keluar dari tubuh setelah 20-30 tahun (Istarani dan Pandabesie, 2014).

Nilai bahaya target telah dikembangkan oleh USEPA untuk mengevalusi kemungkinan dampak terburuk yang akan ditimbulkan akibat mengkonsumsi makanan yang tercemar logam berat. Nilai THQ berguna sebagai parameter penilaian resiko kesehatan manusia terhadap logam berat (Rayyan et al., 2019). Berdasarkan hasil perhitungan nilai bahaya target (THQ), nilai kisaran Cd diantara 0,161-0,946. Hal ini mengindikasikan bahwa setiap 4 kali dilakukannya pengujian terhadap sampel, nilai THQ pada logam berat Cd kerang $A$. granosa masih lebih rendah dari 1 berdasarkan rata-rata konsumsi daging/jaringan lunak kerang di Indonesia dengan asumsi konsumsi daging kerang $A$. granosa yang terpapar logam berat Cd selama 30 tahun. Hal ini menunjukkan daging kerang darah di perairan Tambak Lorok Semarang masih layak untuk dikonsumsi dan tidak berpotensi mengalami efek buruk bagi penyakit non-kanker bagi masyarakat yang terpapar logam kadmium (Cd). Serta angka konsumsi rata-rata kerang di Indonesia berarti masih lebih rendah dari batas bahaya maksimum konsumsi per harinya. Hal ini sesuai dari pernyataan Yap et al., (2016), apabila nilai $\mathrm{THQ}>1$, maka nilai paparan harian akan melewati nilai RfD yang telah ditetapkan. Sehingga, masyarakat yang mengkonsumsi hasil laut tersebut akan berpotensi mengalami resiko yang buruk bagi kesehatan dari suatu cemaran logam berat. Namun sebaliknya apabila nilai THQ < 1 maka nilai paparan harian belum melewati RfD, sehingga dapat diindikasikan bahwa masyarakat yang mengkonsumsi makanan laut yang tercemar logam berat tersebut tidak berpotensi mengalami dampak kesehatan non-kanker yang buruk. Rendahnya nilai EDI dan THQ menurut Amiard et al (2008), dapat disebabkan oleh beberapa faktor seperti perbedaan rata-rata berat badan, umur, gaya hidup, dan cara memasak makanan.

Pada hasil penilaian Excess Cancer Risk (ECR), berdasarkan Pajanan selama 70 tahun (diasumsikan sebagai daur hidup manusia) menunjukkan bahwa dalam 4 kali dilakukan pengujian, nilai ECR berada pada kisaran 2,6 x 10-5-1,5 x 10-4. Angka tertinggi pada bulan Agustus 2020 dan angka terendah pada bulan Maret 2020. Besaran nilai ECR pada bulan Maret 2020, Juni 2020 dan Juli 2020 belum melewati batas maksimum ECR yaitu $10^{-4}$ (Depkes 2012), sehingga tidak akan berpotensi menimbulkan penyakit kanker. Namun pada pengujian bulan Agustus 2020 menunjukan nilai ECR $>10^{-4}$ sehingga kerang $A$. granosa pada bulan Agustus 2020 dapat berpotensi menimbulkan kanker. Oleh karena itu pada pengulangan bulan Agustus 2020 perlu dilakukan strategi pengelolaan resiko ARKL lebih lanjut untuk bisa memperkirakan batas aman konsentrasi dan batas aman konsumsi supaya bisa meminimumkan resiko terkena kanker yang kemungkinan dapat terjadi.

Besaran nilai EDI, THQ dan ECR yang telah dihitung berbanding lurus dengan nilai kandungan logam berat Cd. Semakin tinggi kandungan logam berat, maka nilai EDI, THQ dan ECR semakin tinggi. Hal ini menunjukkan semakin parahnya pencemaran laut akibat akumulasi logam berat yang dilakukan oleh manusia maka akan semakin parah pada resiko kesehatan manusia. Nilai THQ dan ECR sebagai bentuk penilaian bahwa pencemaran pada perairan tersebut masih tergolong aman dan bisa ditoleransi atau sudah parah sehingga hasil laut dari perairan tersebut sebaiknya dihindari. Sehingga dapat dilakukan monitoring supaya keadaan perairan tetap terjaga.

\section{KESIMPULAN}

Berdasarkan hasil yang diperoleh konsentrasi logam Cd pada kerang $A$. granosa pada bulan Agustus telah melewati batas oleh BSN (2009) sehingga kerang pada bulan Agustus dapat berpotensi menimbulkan kanker, namun belum berpotensi untuk terkena penyakit lainnya, 
sementara pada bulan lain konsentrasi logam Cd pada kerang $A$. granosa masih dibawah baku mutu dan tidak berpotensi untuk menimbulkan penyakit maupun kanker. Perhitungan dengan rumus ARKL ini sangat bermanfaat untuk mengetahui bahwa jaringan lunak kerang $A$. granosa di perairan Tambak Lorok Semarang yang di konsumsi berpotensi terhadap resiko kesehatan ataupun tidak.

\section{DAFTAR PUSTAKA}

Ahyar, Bengen, D.E. \& Wardiatno, Y. 2017. Sebaran dan Bioakumulasi Logam Berat Pb dan Cd pada Bivalvia Anadara nodifera, Meretrix lyrata,dan Solen lamarckii di Perairan Pesisir Selat Madura Bagian Barat. Jurnal IImu dan Teknologi Kelautan Tropis. 9(2):631-643. DOI : 10.29244/jitkt.v9i2.19297

Amiard, J.C., Amiard-Triquet, C., Charbonnier, L., Mesnil, A., Rainbow, P.S. \& Wang, W.X. 2008. Bioaccessibility of Essential and Nonessential Metals in Commercial Shellfish from Western Europe and Asia. Food and Chemical Toxicology. 46(6):2010-2022.

Arifin, Z. \& Byun, S.K. 2001. Heavy metal pollution in sediments of coastal waters of Indonesia. In Proceedings of the Fifth IOC/WESTPAC International Scientific Symposium. IOC WESTPAC, Ministry of Maritime Affairs and Fisheries of South Korea, Seoul. 25-49.

Badan Standarisasi Nasional. 2009. Batas Maksimum Cemaran Logam Berat Dalam Pangan ICS. SNI 7387:2009. 25 hal.

Darmono. 2001. Lingkungan Hidup dan Pencemaran Hubungannya Dengan Toksikologi Senyawa Logam. Ul-Press, Jakarta, hal. 139-142.

Dewi, M.A., Suprapto, D. \& Rudiyanti, S. 2017. Kadar Logam Berat Tembaga (Cu), Kromium (Cr) Pada Sedimen Dan Jaringan Lunak Anadara granosa Di Perairan Tambak Lorok Semarang. Journal of Maquares. 6 (3):197-204. DOI : 10.14710/marj.v6i3.20575

Direktorat Jenderal PP dan PL Kementerian Kesehatan. 2012. Pedoman Analisis Resiko Kesehatan Lingkungan (ARKL). Tentang Petunjuk Teknis Analisis Risiko Kesehatan Lingkungan. Jakarta : 18-32.

Eldrin, Nadya, E.H., Puryanti, D. \& Budiman, A. 2019. Identifikasi Kandungan Timbal (Pb), Tembaga (Cu) dan Kadmium (Cd) pada Air Sungai Malakutan Kota Sawahlunto. 8(1):41-45. DOI: 10.25077/jfu.8.1.41-45.2019

Irwan, R.R., Effendi, M. \& Hamdhani. 2018. Analisis Resiko Kesehatan Pencemaran Logam Berat Pada Tiram (Saccostrea cucullata) Di Pesisir Salo Palai, Propinsi Kalimantan Timur. Jurnal Enggano. 3(2):241-249. DOI : 10.31186/jenggano.3.2.241-249

Istarani, F. \& Pandabesie, E.S. 2014. Studi Dampak Arsen (As) dan Kadmium (Cd) terhadap Penurunan Kualitas Lingkungan. Jurnal Teknik Pomits. 3(1):53-58. DOI : 12962/j23373539. v3i1.5684

Menteri Kesehatan Republik Indonesia. 2019. Peraturan Menteri Kesehatan Republik Indonesia Nomor 28 Tahun 2019 Tentang Angka Kecukupan Gizi Yang Dianjurkan Untuk Masyarakat Indonesia. Jakarta. 33 hal

Nazir, M. 2005. Metode Penelitian. Ghalia Indonesia. Jakarta. 212 hal.

NYSDOH (New York State Department of Health). 2007. Hopewell Precision Area Contamination: Appendix C-NYS DOH. Procedure for Evaluating Potential Health Risks for Contaminants of Concern. https://www.health.ny.gov/environmental/investigations/hopewell/appendc.htm

Purbonegoro, T. 2020. Kajian Risiko Kesehatan Manusia Terkait Konsumsi Makanan Laut (Seafood) Yang Tercemar Logam. Jurnal Oseana, 45(2):31-39 DOI : 10.14203/oseana.2020.Vol.45No.2. 87

Rayyan, M.F., Yona, D. \& Sari, S.H.J. 2019. Health Risk Assessments Of Heavy Metals Of Perna viridis From Banyuurip Waters In Ujung Pangkah, Gresik. Journal of Fisheries and Marine Research. 3(2):135-143. DOI : 10.21776/ub.jfmr.2019.003.02.2

Tielman, E.M., Suprijanto, J. \& Widowati, I. 2018. Safely Intake Number of Macridiscus sp. (Kerang Ceplos) from Tambak Lorok Waters, Semarang, Central Java, Indonesia. IOP Conference Series: Earth and Environmental Science. 116(3):1-7. DOI : 10.1088/1755-1315/116/1/012079

Ulfah, E.S., Rahardja, B.S. \& Pursetyo, K.T. 2019. Studi Kandungan Logam Berat Kadmium (Cd) pada Berbagai Ukuran Kerang Darah (Anadara granosa) di Perairan Pantai Bancaran Kabupaten Bangkalan, Madura. Journal of Marine and Coastal Science. 8(3):107-118. DOI : 10.20473/jmcs.v8i3.21160 
USEPA (United States Environmental Protection Agency). 2011. Exposure Factors Handbook 2011 Edition (Final Report). U.S. Environmental Protection Agency, Washington, DC, EPA/600/R09/052F, 2011. $1436 \mathrm{pp}$

Yap, C.K., Cheng, W.H., Karami, A. \& Ismail, A. 2016. Health risk assessments of heavy metal exposure via consumption of marine mussels collected from anthropogenic sites. Science of the Total Environment, 553:285-296. DOI : 10.1016/j.scitotenv.2016.02.092

Yulianto, B., Suwarno., Amri, K., Oetari, S., Ridho, A. \& Widianarko, B. 2006. Penelitian Tingkat Pencemaran Logam Berat di Pantai Utara Jawa Tengah,. Badan Penelitian dan Pengembangan Jawa Tengah, 138 hal. 